\title{
Torture in Lawful Custody: Violation of United Nations Convention against Torture in Criminal Justice System in Bangladesh
}

\author{
Md. Monjur Hasan1,2, Md. Arifuzzaman³, Mohammad Mizanur Rahaman ${ }^{4}$ \\ ${ }^{1}$ School of Law and Political Science, Ocean University of China, Qingdao, China \\ ${ }^{2}$ Gono Biswabidyalay (University), Savar, Dhaka, Bangladesh \\ ${ }^{3}$ Institute of Environmental Science, University of Rajshahi, Rajshahi, Bangladesh \\ ${ }^{4}$ Supreme Court of Bangladesh, Dhaka, Bangladesh \\ Email: monju.law10@gmail.com
}

How to cite this paper: Hasan, Md. M., Arifuzzaman, Md., \& Rahaman, M. M. (2017). Torture in Lawful Custody: Violation of United Nations Convention against Torture in Criminal Justice System in Bangladesh. Beijing Law Review, 8, 397-422. https://doi.org/10.4236/blr.2017.84022

Received: June 17, 2017

Accepted: November 14, 2017

Published: November 17, 2017

Copyright $\odot 2017$ by authors and Scientific Research Publishing Inc. This work is licensed under the Creative Commons Attribution International License (CC BY 4.0).

http://creativecommons.org/licenses/by/4.0/

(c) (i) Open Access

\begin{abstract}
This paper emphasizes on the effective implementation of United Nation Convention against Torture in Bangladesh because torture is a common scenario in the country right now, especially in lawful custody as a part of criminal justice system. Everyday this inhuman practice is taking place in Bangladesh which is not expected because torture represents the uncivilized human society. This practice must be stopped in every modern welfare state like Bangladesh. The Government of Bangladesh has ratified the "Convention against Torture and Other Cruel, Inhuman or Degrading Treatment or Punishment, 1984" and accordingly passed Torture and Custodial Death (Prevention) Act in 2013 in its parliament but the Act has failed to fulfill the objectivity of UN Torture Convention. Torture is frequently practised in lawful custody mostly by Police, Rapid Action Battalion (RAB), and other law enforcement agencies. Moreover, the government has not been able to take any step to compensate and rehabilitate the victims. Several human rights organizations are involved in Bangladesh to work against such malpractices as now it is a much talked issue in the civil society along with these organizations. There is no rigorous and comprehensive study in this field. This study is a very time bound exposition in the proposed field.
\end{abstract}

\section{Keywords}

Torture, Lawful Custody, United Nation, Criminal Justice, Violation

\section{Introduction}

Human Rights are defined as basic rights that encompass civil and political 
rights, the right to life and liberty, freedom of thought and expression, equality before the law, social, cultural and economic rights, the right to food, the right to work, and the right to education and so on. One of the most atrocious violations against human dignity is the act of torture, the result of which destroys the dignity and weakens the capability of victims to continue their lives and their activities. Torture is visible in all societies since time immemorial. At the end of the Second World War, torture made its place within the state in different form and nature. World is in deep concern regarding this type of violation of human rights. It has nothing to do due to the narrow concept of sovereignty. Bangladesh is not an exception to this notion.

The United Nations has different endeavors to recognize universal respect and to protect the human rights. UN Charter is thus considered as one of the vital international instrument. Later, Universal Declaration of Human Rights $1948^{1}$ and International Covenant on Civil and Political Rights $1966^{2}$ mentioned the rights of human being and urged that no one shall be subjected to torture or to cruel, inhuman degrading treatment or punishment. Bangladesh has adopted these provisions in her Constitution. ${ }^{3}$ In light of these conventions, present research focuses on torture taking place in Bangladesh.

\section{Definition of Torture}

Torture is the act of inflicting severe pain, whether physical or psychological, as a means of punishment, revenge, forcing information or a confession, or simply as an act of cruelty. Throughout history, torture has taken on a wide variety of forms, and has often been used as a method of political re-education, interrogation, punishment, and coercion. In addition to state-sponsored torture, individuals or groups may be motivated to inflict torture on others for similar reasons to those of a state; however, the motive for torture can also be for the sadistic gratification of the torturer. In the case of Aksoy vs Turkey, the court discussed about torture as, "if an individual is taken into police custody in good health and found injured at the time of release and also found that the treatment inflicted to the arrestee is deliberate, serious and cruel it will be treated as torture."4

UN Torture Convention defines torture as, any act by which severe pain or suffering, whether physical or mental, is intentionally inflicted on a person for such purposes as obtaining from him or a third person, information or a confession, punishing him for an act he or a third person has committed or is suspected of having committed, or intimidating or coercing him or a third person, or for any reason based on discrimination of any kind, when such pain or suffering is inflicted by or at the instigation of or with the consent or acquiescence of a public official or other person acting in an official capacity. It does not include pain or suffering arising only from, inherent in or incidental to lawful

\footnotetext{
${ }^{1}$ Article 5 of Universal Declaration of Human Rights, 1948.

${ }^{2}$ Article 7 of ICCPR, 1966.

${ }^{3}$ Article 35 of the Constitution of the People's Republic of Bangladesh, 1972.

${ }^{4}$ Aksoy v. Turkey, 23 Eur. H.R. Rep. 553 (1997).
} 
sanctions. ${ }^{5}$

Actions which fall short of torture may still constitute cruel, inhuman or degrading treatment under Article 16 of Convention against Torture. ${ }^{6}$

Torture is prohibited under international law and the domestic laws of most countries in the 21 st century. It is considered to be a violation of human rights, and is declared to be unacceptable by Article 5 of the UN Universal Declaration of Human Rights. Signatories of the Third Geneva Convention and Fourth Geneva Convention officially agree not to torture prisoners in armed conflicts. Torture is also prohibited by the United Nations Convention against Torture, which has been ratified by 147 countries (UN, 2016).

National and international legal prohibitions on torture derive from a consensus that torture and similar ill-treatment are immoral, as well as impractical (General Information Leaflet: Torture and Ill Treatment in the War on Terror). Despite these international conventions, organizations that monitor abuses of human rights, e.g. Amnesty International, the International Rehabilitation Council for Torture Victims report widespread use condoned by states in many regions of the world (Amnesty International Report 2005 and 2006).

Amnesty International (AI) estimates that at least 81 world governments currently practice torture, some of them openly (Amnesty International, 2008).

\section{Victims and Perpetrators of Torture}

Anyone can be a victim of torture-children as well as adults, young as well as old, religious as well as atheists, intellectuals and the uneducated alike.

Nobody should be considered immune, although being a member of a particular political, religious, ethnic group or minority can very often set individuals aside as targets for government endorsed violence. Frequent victims include politicians, union leaders, journalists, health professionals, human rights defenders, people in detention or prison, members of ethnic minorities, and student leaders.

Perpetrators are those most likely to be involved in torture include persons such as: prison officers/detention staff, the police, the military, paramilitary forces, state-controlled contra-guerilla forces, but perpetrators may also include: health professionals, legal professionals, co-detainees acting with the approval or on the orders of public officials and death squads.

\section{Instruments Which Prohibit the Act of Torture}

In different international, regional and constitutional documents, this right of the accused has been preserved carefully. Mention may be made of these provisions in order to illustrate, the importance and significance of this inherent right of the persons accused.

The UDHR states, "No one shall be subjected to torture or to cruel, inhuman

${ }^{5}$ Article 1(1) of the UN Convention against Torture.

${ }^{6}$ Article 16 of the UN Convention against Torture. 


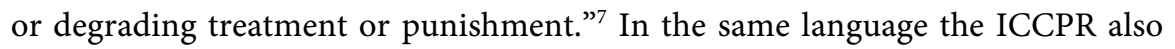
supports the preservation of this right against any kind of torture or punishment. ${ }^{8}$ The European Convention on Human Rights and Fundamental Freedoms holds the same opinion regarding this right. ${ }^{9}$ It has been stated in the American Declaration, "Every individual who has been deprived of his liberty has the right to human treatment during the time he is in custody"10.

Every Person accused of an offence has the right not to receive cruel, infamous or unusual punishment ${ }^{11}$. Again, the American Convention states, "No one shall be subjected to torture or to cruel, inhuman or degrading punishment or treatment. All persons deprived of their liberty shall be treated with respect for the inherent dignity of the human person"12 Another regional instrument on human rights, the African Charter on Human and People's rights (ACHPR) is of opinion that all forms of exploitations and degradation of man, particularly torture, cruel, inhuman, or degrading punishment or treatment shall be prohibited. ${ }^{13}$ These are the important provisions of International and regional documents, which clearly expressed torture of any nature as prohibitive and condemnable and must be stopped in iron hand by the government, as this is the most important function of the government.

\section{UN Torture Convention}

The UN Convention against Torture is designed to prevent the government officials or other acting in an official capacity to commit torture. The convention is divided into three sections. Substantive rights are contained in Articles 1 - 16, implementation machinery is provided in Articles 17 - 24, and clauses relating to ratification, amendments, etc. are contained in the final part consisting of Articles 25 - 32. The preamble of the convention makes reference to the United Nations Charter particularly Article 55, to Article 5 of the UDHR and Article 7 of the ICCPR.

Part I: (Articles 1 - 16) defines torture (Article 1); each state party shall take effective measures to prevent any act of torture in any territory under their jurisdiction (Article 2). These include ensuring that torture is a criminal offense (Article 4), establishing jurisdiction over acts of torture committed by or against a party's citizens (Article 5), ensuring that torture is an extraditable offense (Article 8), and establishing [universal jurisdiction] to try cases of torture where an alleged torturer cannot be extradited (Article 5). Parties must promptly investigate any allegation of torture (Articles 12 and 13), and victims of torture must have an enforceable right to compensation (Article 14). Parties must also ban the use of evidence produced by torture in their courts (Article 15), and are barred

\footnotetext{
${ }^{7}$ Article 5 of the Universal Declaration Human Rights (UDHR).

${ }^{8}$ Article 7 of International Covenant on Civil and Political Rights (ICCPR) 1966.

${ }^{9}$ Article 3 of European Convention on Human Rights and Fundamental Freedom (ECHRFF), 1950.

${ }^{10}$ Article XXVI of American Declaration of the Rights and Duties of Man (ADRDM), 1948.

${ }^{11}$ ibid.

${ }^{12}$ Article 5(2) of American Convention on Human Rights, 1969.

${ }^{13}$ Article 5 of African Charter on Human and Peoples' Rights, 1986.
} 
from deporting, extraditing or befouling people where there are substantial grounds for believing they will be tortured (Article 3).

Parties are also obliged to prevent other acts of cruel, inhuman or degrading treatment or punishment, and to investigate any allegation of such treatment within their jurisdiction (Article 16).

Part II: Articles 17 - 24 governs reporting and monitoring of the Convention and the steps taken by the parties to implement it. It establishes the Committee against Torture (Article 17), and empowers it to investigate allegations of systematic torture (Article 20). It also establishes an optional dispute-resolution mechanism between parties (Articles 21) and allows parties to recognize the competence of the Committee to hear complaints from individuals about violations of the Convention by a party ${ }^{14}$

Part III: Articles 25 - 33 governs ratification, entry into force, and amendment of the Convention. It also includes an optional arbitration mechanism for disputes between parties. ${ }^{15}$

\section{UN Committee against Torture}

The Committee against Torture (CAT) is the body of ten independent experts that monitors implementation of the Convention against Torture and Other Cruel, Inhuman or Degrading Treatment or Punishment by its State parties.

All States parties are obliged to submit regular reports to the Committee on how the rights are being implemented. States must report initially one year after acceding to the Convention and then every four years. The Committee examines each report and addresses its concerns and recommendations to the State party in the form of "concluding observations". Bangladesh is yet to submit its report.

\section{Criminal Justice System in Bangladesh}

The criminal justice system refers to the system used by the government to maintain social control, enforce laws, and administer justice. It has become a basic necessity in every society as an ally of the State in the maintenance of law and order. The present legal and judicial system of Bangladesh owes its origin mainly to two hundred years British rule in the Indian Sub-Continent although some elements of it are remnants of Pre-British period tracing back to Muslim and Hindu administration (Kulshreshtha's, 1995).

The criminal process in Bangladesh is essentially, adversarial in nature. That means the whole process is a contest between two parties. As regards crime, these two parties are the state on the one hand and the person accused of the crime concerned on the other hand. In the process court takes a non-partisan role. Court plays no significant role in preparation of a case. The trial itself is not an investigation into events or allegation but rather a hearing to decide within a complex set of rules, whether the accused is proved to be guilty of the particular

\footnotetext{
${ }^{14}$ Article 22 of UN Torture Convention.

${ }^{15}$ Article 30 of the UN Torture Convention.
} 
offences which the prosecution have charged him with. A person accused of a crime is presumed to be innocent until the prosecution proves his guilt beyond every reasonable doubt. Criminal justice consists in the punishment of wrongs if proved. All criminal proceedings in Bangladesh are regulated under the Code of Criminal Procedure (CrPC), 1898 and Criminal Rules and Orders unless otherwise excluded or specifically provided for. Four agencies are involved in a Criminal administration of justice: Police, Prosecution, Courts, Jail and Probation authority.

\subsection{Stages in Criminal Proceedings}

The stages may be divided into four periods (Halim, 2009)

1) Pre-Proceeding stage (which is the initial stage of inquiry or investigation and preparation of a criminal case)

2) Proceeding stage (Court)

3) Trial stage (Court)

4) Post trial stage (police or jail authority or probation authority etc).

\subsection{Police Custody and Arrest}

There are two kinds of offences in Bangladeshi criminal law. They are, cognizable and non-cognizable. Cognizable offences, as enumerated in Section 4 (f) of the Code of Criminal Procedure, 1898 are those in which a police officer may arrest without warrant and it includes the crimes such as murder, robbery, theft, rape, rioting and assault. In case of non-cognizable offences a police officer requires a warrant before making an arrest of accused.

Under Section 54 of the CrPC any police officer may, without an order from a Magistrate or a warrant arrest a person who:

1) is concerned in any cognizable offence or against whom a complaint has been lodged or credible information received or reasonable suspicion exists of his being so concerned;

2) possesses any implement of house-breaking;

3 ) is a proclaimed offender;

4) is suspected of having stolen property in his possession;

5) obstructs a police-officer in performing his duty or who has escaped or attempts to escape from lawful custody;

6) is suspected of being deserter from the armed forces;

7) is concerned in or against whom a complaint has been lodged or credible information received or reasonable suspicion exists of his being so concerned in any act committed at any place out of the country, which if committed in the country would have been punishable offence and for which he is subject to extradition or under the Fugitive Offender Act, 1881 is liable to be apprehended in custody;

8) is a released convict committing a breach of any rule made by magistrate under Section 565 (3) of the Cr. P.C; or 
9) is subject to arrest following a requisition received from another police officer.

As stated by many human rights activists and lawyers met by the Researcher in Bangladesh, police very often abuse this power of unwarranted arrest under Section 54. Several of the nine circumstances enumerated in section 54 of the Criminal Procedure Code are drafted with such nebulous wording that they facilitate this abuse of power. The Supreme Court itself has called for a revision of the provision, especially Section 54 (a), which allows unwarranted arrest upon "reasonable suspicion," "reasonable complaint," or "credible information" against "any person who has been concerned in any cognizable offence." This section is a virtual carte blanche for the police to abuse their power of arrest without a warrant due to the nebulous phrases "concerned in any cognizable offence" and "reasonable suspicion."

As in other common law countries, statutory "reasonable suspicion" wording has been interpreted by the High Court Division of the Bangladesh Supreme Court into an articulable standard, that the arresting officer had "actual knowledge of underlying facts that lead to the suspicion." ${ }^{16}$ Unfortunately, however, this standard has not been enforced or applied by local courts or authorities, which has rendered the Supreme Court's power of statutory interpretation impotent. The rules of the Criminal Procedure Code deal with the investigation and arrest by police therefore facilitate the misuse of the power of arrest without a warrant.

In Bangladesh, every criminal action commences with a First Information Report (FIR), lodged by the victim, relatives, or a witness. The FIR is a written or oral complaint to the investigating officer who must lodge the complaint in writing in the police records per $\mathrm{CrPC}^{17}$.

Several human rights activists and lawyers have told the Researcher that naming a person in a FIR is often a way for people to strike back at their enemies or perpetuate neighborly squabbles. This practice of false, vengeful reporting is particularly common in acid throwing cases and other cases falling under the laws protecting women and children. The nature of the FIR and their accompanying improper police practices allow citizens to manipulate the justice system and to involve it in private conflicts.

After the FIR has been submitted and an arrest is made, according to Article 33 (2) of the Constitution of the People's Republic of Bangladesh, every person who is arrested and detained in custody shall be produced before the nearest magistrate within a period of twenty-four hours of such arrest, excluding the time necessary for the journey from the place of arrest to the court of the magistrate, and no such person shall be detained in custody beyond the said period without the authority of a magistrate. Section 61 of the $\mathrm{CrPC}$ requires that the defendant is brought in front of a magistrate within 24 hours of incarceration in

${ }^{16}$ BLAST and others vs Bangladesh, 55 (2003) DLR (HCD) 363.

${ }^{17}$ Section 154 of the Criminal Procedure Code, 1898. 
order to determine whether further detention is necessary. Under Section 167 of the $\mathrm{CrPC}$, however, magistrates can remand the case for a period not exceeding 15 days at the request of the officer. This infamous remand process has widely been denounced as another vehicle for the abuse of police power. In order to ask for further detention in police custody, police must demonstrate that there are grounds for believing that the accusation or information upon which the arrest is based is well-founded.

However, as stated inter alia by Prof. Shahdeen Malik, "It is common knowledge that Magistrates routinely allow this request for remand" (Malik, 2007). The remand period is critical because it opens the door to severe human rights violations. Ill treatment, torture and extra-judicial killings in custody are commonplace. Much of this torture and abuse takes place because police hope to extract bail money from the accused during the detention period. This issue was addressed in the BLAST ${ }^{18}$ judgment ${ }^{19}$ of 2003, in which the High Court Division of the Supreme Court of Bangladesh called for the strict adherence to Constitutional guarantees of due process and condemned the systematic police practices of torture and extortion.

As for the remand process, the court in the BLAST case condemned the police practice of trying to extort information or confession from the person arrested by physical or mental torture as violating Article 35 of the Constitution's right to life and right to be free from self incrimination. Magistrates must also take all three subsections of Section 167 of the CrPC into consideration when deciding if remand is proper, which include whether the investigation requires more than 24 hours, if there are grounds for believing that the accusation or complaint is well founded, and if the officer has submitted his diary, which must include the time and place of the occurrence and the articulated reasons for the arrest.

While the BLAST judgment is a very positive step towards a more effective right to liberty and a police custody without ill-treatment, torture and death custody, it is not sufficient to reform the law enforcement agencies and foster a culture of respect for human rights amongst their members.

Torture and custodial deaths are facilitated not only by the provisions of the CrPC but also by the widespread corruption in the ranks of law enforcing agencies. Delay plagues the administration of justice in Bangladesh at each level of the judiciary, such lengthy delay compounds concerns about denial of bail to accused and raises serious questions about the presumption of innocence in Bangladesh's criminal justice system.

\section{Laws Relating to Safeguards for Torture: Bangladesh Perspective}

Bangladesh ratified The UN Torture Convention (Convention against Torture and other Cruel, Inhuman or Degrading Treatment or Punishment, 1984) on 5 October 1998 and as such it is a state party to this Convention and it has become

\footnotetext{
${ }^{18}$ Bangladesh Legal Aid and Services Trust (BLAST).
}

${ }^{19}$ BLAST and others, 55 (2003) DLR (HCD) 363. 
obligatory on it to eliminate torture.

The Constitution of Bangladesh and criminal law absolutely forbid in all circumstances, any actions amounting to torture. Constitution of Bangladesh states that, "No person shall be subjected to torture or to cruel, inhuman or degrading punishment or treatment." ${ }^{20}$ Section 29 of the Police Act 1861 and section 48 of the Dhaka Metropolitan Police Ordinance, 1976 also speak against torture. Article 35(4) of the Constitution of Bangladesh has stated that no person accused of any offence shall be compelled to be a witness against himself. Bangladesh Constitution also states that "No person shall be deprived of life or personal liberties save in accordance with law." 21

The Penal Code 1860(PC) applicable in Bangladesh makes clear that physical and psychological ill-treatment of the accused by law enforcement officials is impermissible and punishable. Causing of "hurt" or "grievous hurt" by public servants to obtain confessions or to compel restoration of property carry sentences up to seven and ten years imprisonment respectively under section 330 and 311. Sections 162,163,172 and 173 of the Code of Criminal procedure, 1898; read with sections 24, 25 and 26 of the Evidence Act, 1872 provide rules of conduct and procedure to prevent torture of persons under interrogation. Section 24 of the Evidence Act lays down that a confession by an accused person is irrelevant if it appears to have been caused by an inducement or threat. Section 25 provides that no confession made to a police officer shall be proved as against the accused person. Section 26 excludes confessions made by a person in Police custody unless made in the immediate presence of a magistrate. It is to be read with section 164 of the CrPC.

Article 2 (1) and Article 4 of the UN Torture Convention require the state party acceding to it to enact a domestic law to recognize an act of torture, cruel, inhuman and degrading punishment and treatment, as a crime in the country. Bangladesh has enacted The Torture and Custodial Death (Prevention) Act in 2013. This Act was not made by pursuing the Convention against Torture because most of the sections of this Act go against the core spirit of the said convention. Section 2 (6) has defined torture which has not closer conformity with Article 1 of CAT. In Section 4, the phrase "The Court having jurisdiction" should be clarified. Section 5 of the Act should be amended by adding the provision of judicial investigation instead of the current provision of investigation against the law enforcement agencies by the law enforcement agencies. In this process the member of Law enforcement agency who is appointed as investigating officer may become bias to investigate against the accused. The Act does not include a definition of "person" to remove ambiguity of meaning of some provisions like sections 6 (1), 7 (1), 8 (3) and 13 (1), (2) of the Act. Therefore, the Act should include a definition of the word "person" mentioned especially in section 13 (1) meaning public official or other person acting in an official capacity in conformity with the Convention against Torture.

\footnotetext{
${ }^{20}$ Article 35 (5) of the Constitution of Bangladesh.

${ }^{21}$ Article 32 of the Bangladesh Constitution.
} 


\section{Laws Which Are Misused by Law Enforcing Agency in Practicing Torture}

Despite torture has been the most widespread and persistent human rights violation in Bangladesh yet it has been routinely ignored by successive governments since Bangladesh's independence in 1971. Perpetrators are mostly Police personnel, Rapid Action Battalion (RAB), Border Guard Bangladesh and other law enforcement and Para-military agencies. Irrespective of the political identity, all successive governments had passed, experimented and used repressive laws, regulations, ordinances etc in the pretext of protecting public interests and ensuring public safety (The Special Powers Act, 1974; The Public Safety Act, 2000 (now repealed); Speedy Trial Act, 2002). In reality, those laws have often been used unscrupulously and indiscriminately on the people overlooking or disregarding the safeguards guaranteed by the Constitution to the people. Consequently, political parties while in opposition also criticise application of those laws and have demonstrated commitment to repeal the same if elected (the Special Powers Act, 1974, for example). However, once elected to power the same deliberately choose not to do away with the draconian Act for its use as a lethal tool to detain political rivals.

In recent years, Civil society, Human rights groups and Media have shown serious concern about the arbitrary use of Section 54 of the Code of Criminal Procedure (CrPC) and section 86 as well as section 100 of Dhaka Metropolitan Police Ordinance, and similar provisions under other Metropolitan Police Acts and Ordinances. The said provisions of laws have vested unfettered and unbridled power with the police to arrest a person without warrant.

Article 32 of the Constitution concisely provides that nobody should be deprived of the most cherished and indefeasible right to life and personal liberty save in accordance with law. However, Section 54 of the CrPC allows enough room for the police to curtail personal liberty of people in violation of Article 32. Sensing that police may abuse the power against the spirit of Article 32, the framers of the Constitution incorporated Article 33, which guarantees certain safeguards in respect of arrest and detention. The safeguards broadly are rights to be informed of the grounds for arrest, consulted and be defended by a legal practitioner, and the requirement of producing the arrestee before the nearest Magistrate within 24 hours of arrest. Non-applicability of the above provisions in case of preventive detention Article 33(1) (d)) was incorporated through Second Constitutional Amendment Act, 1973. Before, Second Amendment there was no scope for preventive detention. Inclusion of Article 33 (d) provided the legal basis for all preventive detention laws to come into force. Despite further Constitutional safeguards, such as, clauses (4) (5) of Art.33, these laws have been routinely abused by the police.

\section{A Culture of Impunity Consecrated by Bangladeshi Law}

The Constitution of Bangladesh is ambiguous on torture. While Article 35 (5) 
prohibits torture, Article 46 allows the Parliament to enact law to acquit "any person in the service of the Republic or any other person in respect of any act done by him in connection with the maintenance or restoration or order in any area in Bangladesh or validate any sentence passed, punishment, forfeiture ordered, or other act done in any such area". In other words, Article 46 of the Constitution allows the Parliament to indemnify human rights violations of state officials, including torture, by enacting legislation. According to the Human Rights Committee, amnesty for acts of torture is not compatible with Article 7 of the ICCPR. ${ }^{22}$ Moreover, recalling that the prohibition of torture is non-dirigible and absolute. ${ }^{23}$

Furthermore, the Code of Criminal Procedure encourages a culture of impunity and protects the perpetrators of torture. Under Section 132 of the Code of Criminal Procedure, no criminal complaint can be lodged against any State official without prior approval from the Government. This provision is questionable under Article 12 of the CAT which imposes on State parties to promptly and impartially investigate allegations of torture. It is also a violation of Article 13 which states "that any individual who alleges he has been subjected to torture in any territory under [the] jurisdiction [of a State party] has the right to complain to, and to have his case promptly and impartially examined by, its competent authorities".

Usually sections 54, 167 and 344 of the Code of Criminal Procedure and Section 3 of Special Powers Act 1974 are mostly misused by Police.

\section{Directives and Guidelines of the Honourable Supreme Court of Bangladesh to Stop Torture}

Following disturbing and depressing reports by the media and public outcry on increasing police abuses and custodial death in Bangladesh which included the death of Rubel, ${ }^{24}$ Shima Chowdhury ${ }^{25}$ and Arun Chakroborti, ${ }^{26}$ BLAST along with other human rights organisations brought a writ petition before the Supreme Court of Bangladesh. Subsequently, on April 7, 2003, a Division Bench of the High Court ${ }^{27}$ Division provides clear guidelines in the form of fifteen directives on arrest, detention, remand and treatment of suspects to be followed by law enforcement agencies and magistrates. Again, the Supreme Court ${ }^{28}$ issued certain guidelines to be followed by the government, magistrates and police with respect to arbitrary arrest, detention, remand, investigation and treatment of suspects.

\footnotetext{
${ }^{22}$ See Human Rights Committee, General Comment No 20: Article 7 (Prohibition of torture, or other cruel, inhuman or degrading treatment or punishment), paragraph 15 .

${ }^{23}$ Convention against Torture, General Comment No. 2, CAT/C/GC/2, paragraph 5.

${ }^{24} \mathrm{~A}$ student of the Independent University, Bangladesh who was picked up by the police and later died in their custody in 1998.

${ }^{25}$ A young woman who was picked up by the police and raped at Raojan Police Station in Chittagong on 9 October, 1997.

${ }^{26} \mathrm{~A}$ young boy lost his life in police custody at Malibagh Police Station in Dhaka, 1998.

${ }^{27}$ BLAST and others vs. Bangladesh (2003) 55 DLR 363.

${ }^{28}$ Saifuzzaman vs. State (2004) 56 Dhaka Law Report (DLR) 324.
} 
In both BLAST and others vs. Bangladesh and Saifuzzaman vs. State cases, the subject of torture was considered and the Judges issued directives and guidelines with a view to prevent such heinous practices by the police. For the convenience of discussion the relevant directives and guidelines of the Supreme Court relating to torture, remand or custodial violence are mentioned below.

1) No Police officer shall arrest anyone under Section 54 of the CrPC for the purpose of detention under Section 3 of the Special Powers Act, 1974.

2) A police officer shall disclose his/her identity and show his/her ID Card on demand to the person arrested or those present at the time of arrest.

3) A record of reasons of arrest and other particulars shall be maintained in a separate register till a special diary is prescribed.

4) The concerned officer shall record reasons for marks of injury, if any, on the person arrested and take him/her to nearest hospital or government doctor.

5) The person arrested shall be furnished with reasons of arrest within three hours of bringing him/her to the Police Station.

6) If the person is not arrested from his/her residence or place of business, the relatives should be informed over the phone or through messenger within one hour of bringing him/her to Police Station.

7) The person concerned must be allowed to consult a lawyer of choice or meet nearest relations.

8) While producing the detained person before the Magistrate under Section 61 of the $\mathrm{CrPC}$, the police officer must forward reasons in a forwarding letter under Section 167 (1) of the CrPC as to why the investigation could not be completed within twenty four hours and why s/he considers the accusation and information to be well founded.

9) On perusal of the forwarding letter, if the Magistrate satisfies him/herself that the accusation and information are well founded and materials in the case diary are sufficient for detaining the person in custody, the Magistrate shall pass an order of detention and if not, release him/her forthwith.

10) Where a person is released on the aforesaid grounds, the Magistrate shall proceed under 190 (1) (c) of the CrPC against the Officer concerned under Section 220 of the Penal Code.

11) Where the Magistrate orders detention of the person, the Officer shall interrogate the accused in a room in a jail until a room with glass wall or grille on one side within sight of lawyer or relations is constructed.

12) In any application for taking accused in custody for interrogation, reasons should be mentioned as recommended.

13) The Magistrate while authorizing detention in police custody shall follow the recommendations laid down in the judgment.

14) The police officer arresting under Section 54 of the CrPC or the Investigating Officer taking a person to custody or the jailor must inform the nearest Magistrate about the death of any person in custody in compliance with these recommendations. 
15) The Magistrate shall inquire into the death of any person in police custody or jail as per the recommendations.

Any kind of death in police custody is unexpected and unwarranted. Police are meant to protect people's life not to kill them. While death may happen naturally or following injury sustained before arrest, the most unacceptable death in police custody is one which results from torture. Indian Supreme Court $^{29}$ observed that custodial death is one of the worst crimes in a civilised society governed by the rule of law. In the same judgement the court held "[I]f the functionaries of the government becomes law-breakers, it is bound to breed contempt for law and would encourage lawlessness leading to anarchism."

In BLAST and others vs. Bangladesh the Supreme Court considered the issue of granting compensation to a victim of torture in police custody and the nearest relatives of a person who died in police custody. The Judges were of the opinion that "compensation may be given by this Court when it is found that confinement is not legal and death resulted due to failure of the State to protect the life." The Court however, did not award compensation in this case on the grounds that the subject matter of the case was pending before the competent court.

Article 9 of the Covenant on Civil and Political Rights states that "anyone who has been the victim of unlawful arrest or detention shall have an enforceable right to compensation." ${ }^{30}$

\section{Some Incidents of Torture by Law Enforcing Agencies}

In spite of constitutional guarantees of the right to be free from torture, inhuman, cruel and degrading punishment, both physical and psychological, torture by the Law Enforcing Agencies (LEA) are widely reported to be used in Bangladesh. In spite of constitutional provisions, torture especially by the Police and Jail authority has become a routine work. Almost every day we come to know through dailies and human rights journals the sad incidents of torture, degrading punishment, and inhuman treatment by the LEA. They torture the victims by using different methods which include beating with rifle butts, iron roads, bamboo sticks, or bottle filled with hot water so they do not leave marks on the body, hanging by the hands, water treatment in which hose pipes are fixed into each nostril and taps turned on full for two minutes at a time, the use of pliers to crush fingers and electric shocks, burning by fire or cigarette etc beating with the arrestee hung from the roof, indiscriminately kicking several arrestees together and coercing to elicit information and extract confession ${ }^{31}$. The following incidents of torture will show the picture of torture in criminal justice system in Bangladesh:

Ujjal, a resident of Munshigonj district, was arrested by police under section 54 of the CrPC on 3 August, 2000 while he was returning after watching a movie.

${ }^{29}$ D. K. Basu vs. State of West Bengal (1997) 1 SCC, p. 434.

${ }^{30}$ Article 9 of the International Covenant for Civil and Political Rights (ICCPR).

${ }^{31}$ Annual Reports of Bangladesh Rehabilitation Centre for Trauma 1997, state of Human Rights, 50. 
He was taken to Munshigonj police station where he was beaten mercilessly by a police officer with a ruler. On 30 July he was sent to jail and was detained for 27 days (The Daily Star, 2000).

On 3 August, 2000 Shadhu Baran Shil, a vegetable seller was arrested under section 54 of the CrPC and tortured by Munshigonj police station. Police demanded 200 taka from him. But he had no money at that time (The Daily Star, 2000).

In the like manner, Bahauddin Nasim, personal assistant to the leader of the then opposition, Sheikh Hasina, was arrested on 28 February 2002 under section 54 of the CrPC without warrant and he was taken to remand for ten days. He was released ten months and six days after arrest following an order by the High Court Division.

On the basis of a report published in various newspapers titled "Madrasa teacher died due to torture in RAB custody." Odhikar investigated the matter on spot with assistance from Academy for Educational Development (AED). ODHIKAR found that M. Shah Newaz Titu (30) was brutally tortured to death by Rapid Action Battalion (RAB) on 6 August 2004 at Choumohani area under Double Mooring thana in Chittagong. He was an assistant Teacher of Ketua Islamia Dakhil Madrasah in Chandpur. It was learnt that on 2 August 2004, Shah Newaz came with his cousin Munir Hossain Talukdar to the residence of his another cousin Margina Begum at Choumohani, Agrabad and he was totally innocent (The Bangladesh Today, 2004).

RAB has been held responsible for over 1000 custodial deaths since its inception in 2004. Reports claim that six people have been killed in custody even after the direction given by the High Court Division of the Supreme Court against custodial torture (Hossain, 2010).

The two young men named Azizur Rahman Shohel, and Atiqur Rahman Jewel (They were the sons of Abdur Rashid and resided in Puratan Bilsimla area, Boalia Police Station, Rajsahi, Bangladesh ) were brutally tortured by the Boalia police on 27 July 2005. The police also tortured the victims using electric shocks. The alleged reason for this inhuman act was that the victims' family did not give the requisite bribe to the police. The brothers were tortured to such an extent that they were hospitalized at the Rajshahi Medical College Hospital under police custody ${ }^{32}$.

On May 27, 2009 RAB killed two Dhaka polytechnic students, Mohammad Ali Jinnah and Mohsin Sheikh, in what RAB referred to as a "shootout." However, witnesses stated that the two men were arrested at night at their campus. Jinnah's family has filed a murder case against 10 RAB officers questioning how the victims, while allegedly running to escape, were shot in the chest, abdomen, and throat (Human Rights Watch, 2010).

On October 22, 2009 F. M. Masum, a journalist at the New Age newspaper, was detained by RAB officers and tortured. Masum has written several reports

${ }^{32}$ http://www.humanrights.asia/news/urgent-appeals/UA-133-2005 [Accessed on 13 June 2016]. 
about the paramilitary unit for New Age, including on its involvement in extrajudicial killings (Human Rights Watch, 2010).

The case of Mr. Mahmudur Rahman, the Acting Editor of the daily Amar Desh, unfortunately illustrates the abuse of power by the police on remand. Mr. Rahman was arrested by the police on 2 June 2010, after the daily's publisher filed a fraud case against him allegedly at the instigation of the National Security Intelligence (NSI). When he was produced before a court at the end of his remand, Mr. Mahmudur Rahman alleged he has been tortured in detention (Mahumudur Alleges Torture in Remand). Subsequently, Mr. Rahman has been charged with sedition for allegedly meeting with people attempting to overthrow the government in 2006, which allows for indefinite remand. Writers and reporters, detained for sedition, report that mistreatment, malnutrition and torture are common. ${ }^{33}$

In the end of June 2010, three persons, Mizanur Rahman, Mujibur Rahman and Babul Kazi died in police custody. In the case of Mizanur Rahman, police allegedly shot and killed him upon failure to produce money that police had demanded from him (Odhikar's Human Rights Monitoring Report, 2010). It is clear, therefore, that torture and custodial deaths are facilitated not only by the provisions of the CrPC but also by the widespread corruption in the ranks of law enforcing agencies. After the three custodial deaths mentioned above, the High Court asked the Dhaka Metropolitan Police Commissioner to submit inquest reports on these cases and to turn in a report by the end of July on measures to prevent lock-up deaths. The High Court also asked the Government to explain, within two weeks, why it does not take punitive action against the police officers responsible for the custodial deaths. When this report was not submitted, the Police Commissioner Md. Muniruzzaman was charged with contempt of court, but was subsequently cleared of the contempt charges after offering an "unqualified apology" and suspending the investigating officer suspected of the custodial death. ${ }^{34}$

On January 11, 2011, Imtiaz Hossain Abeer (19) a first year College student, was shot dead by police at the Pallabi area in Dhaka city. The relatives of the deceased alleged that Abeer was shot dead by police. There was no case diary against Abeer in any police station (Fact finding report of Odhikar).

Rapid Action Battalion (RAB) has shot a juvenile college student causing a permanent disability in Jhalkathi district. On 23 March 2011, a team of the RAB-8 stopped 16-year-old Limon Hossen, who was an examinee of the Higher Secondary Certificate near to his house and shoot him in his thigh on the suspicion that he was a terrorist. As a result of this deliberate shooting the left leg of Limon has been cut off by the doctors of the National Institute of Traumatology, Orthopedic and Rehabilitation (NITOR) as all the tissues were found completely

\footnotetext{
${ }^{33}$ Detained editor Mahmudur Rahman now facing sedition charge", IFEX, 10 June 2010, available at: http://www.ifex.org/bangladesh/2010/06/10/rahman_sedition_charge. [Accessed on 13 July 2010].

${ }^{34}$ "Enough with custodial deaths, says HC", bdnews24, 1 June 2010, available at: http://www.bdnews24.com/details.php?id=163013\&cid=2. [Accessed on 12 January 2010].
} 
damaged. Investigation by government has proved Lemon innocent. ${ }^{35}$

Dhaka University student Abdul Kader on July 15, 2011, was arrested by the police at Segunbagicha while he was walking back to his university dormitory from his aunt's house as he did not get any transport. Then he was intercepted and brutally tortured by police in custody. A false case of mugging was filed against him. ${ }^{36}$

On February 29, 2012, Mohammad Abdur Rahim (60) of Sahapur Mistripara village under Badarganj Municipality in Rangpur District was allegedly tortured by police of the Badarganj Police station. Later he was produced before a Mobile Court and sentenced one year imprisonment for taking drugs. On March, 2, 2012 at around 1:50 PM Mohammad Abdur Rahim sheikh died in the Intensive Care of Rangpur Medical College Hospital where he was under treatment. His family alleged that the police severely tortured him after the arrest and as a result he died. ${ }^{37}$

On September 1, 2013, Samshed Hawlader suspiciously died under treatment in the prison cell of Barishal Sher-e-Bangla Medical College Hospital. The family complained that after arresting the victim the Sub-inspector of Metro Politon Police of Detective Brance Helal Uddin killed him by torture. ${ }^{38}$

On November 17, 2013, a man named Jafar was killed in jail in Kustia, Daulatpur Police Station. His family member claimed that the police demanded 30 thousand taka bribe from him, and since they did not get the money, he was killed after physical torture. ${ }^{39}$

On March 3, 2014 at around 11.00 am, contractor Mohammad Washim and his assistant Songram Chowdhury were killed in “crossfire” by RAB at Washim's residence at $131 \mathrm{New}$ Jurain under Kadamtoli Police Station in Dhaka. Families of the deceased men claimed that they were shot and killed in their presence by RAB. Sonia Begum, wife of Washim and Salma Chowdhury, wife of Songram alleged that some of Washim's employers were also beaten after being arrested by $\mathrm{RAB}$ and were forced to make false statements that Washim and Songram had abducted them (Odhikar, 2014).

On February 2, 2015 a team from Pallabi Police Station, led by Sub Inspector (SI) Touhidul Islam, picked up Nahid, in front of Proshika Bhaban at Mirpur-6 in Dhaka. Police informed Nahid's father on his cell phone that Nahid would be released in exchange of five hundred thousand taka (Bangladeshi Currency).

\footnotetext{
${ }^{35}$ Asian Human Rights Commission report.

${ }^{36}$ The Daily New Age 18 July, 2011; Available at:

http://www.newstoday.com.bd/index.php?option=details\&news_id=35038\&date=2011-08-02

[Accessed on 6 December 2011].

37"Extra Judicial killings by Law enforcing agencies in Bangladesh" October, 14, 2012, Available at: http://belalpacs.blogspot.com/2012/10/extra-judicial-killings-by-law.html

[Accessed on 6 June 2017].

${ }^{38}$ Deaths in Jail Custody|January-December 2013, Available at:

http://www.askbd.org/ask/2014/01/27/death-jail-custody-january-31-december-2013/

[Accessed on 10 May, 2017].

${ }^{39} \mathrm{ibd}$.
} 
Nahid was shot dead as his family could not give police the money they demanded. Nahid's father GM Sayeed later identified Nahid's body at the morgue (The Daily Prothom Alo and Odhikar, 2015).

On May 22, 2016 assistant sub-inspector Delwar Hossain of Dagonbhuiyan Police Station under Feni District, with assistance from Officer Abdul Mannan, raped a woman who went to the station to file a complaint over a family dispute. The woman later filed a case under the Women and Children Repression Prevention Act and the authorities brought the two men to court, where they were found guilty and sent to prison (2016 Country Reports on Human Rights Practices).

On the night of August 22, Abdullahil Amaan Azmi, son of convicted war criminal and former Jamaat leader Ghulam Azam, was allegedly abducted from his Dhaka apartment by men in plain clothes who reportedly identified themselves as members of the Detective Branch. Unlike his father, Azmi was never an official member of Jamaat. He is a known figure in Bangladesh politics and active on social media, however, and his Facebook posts were often critical of the government. Similarly, on August 9, Mir Ahmed Bin Quasem, son of top Jamaat leader and convicted war criminal Mir Quasem Ali, was allegedly abducted. Mir Ahmed had been serving as the legal representative for Jamaat until his abduction (2016 Country Reports on Human Rights Practices).

On March 23, 2017 at around 5:00 pm, Sub-Inspector Azadur Rahman arrested an accused person (case No. 59, dated 22/03/2017) named Nurul Amin (54) from South Kashimpur Village under Panchgachhia Union in Feni District and allegedly put him in the lock-up. On the same day he was admitted to Chittagong Medical College Hospital when he became sick. He died there at 3:20 am. Nurul Amin's relative Shahidul Islam said that Nurul Amin was tortured in police custody and as a result he died. Later police staged a "drama" of him becoming ill and hired an ambulance to take him to Chittagong Medical College Hospital. On March 24, police took signatures on a paper from the deceased Nurul Amin's differently abled son Nurul Absar Manik, which says that Nurul Amin died of natural causes (Human Rights Monitoring Report).

So, this is an ongoing malpractice in Bangladesh from a very long time.

20 persons of several police stations of Rajshahi were interviewed from the lists received from police stations. We received information from them regarding the nature of violation of human rights including the treatment they received from the executives under police or jail custody or during remand. They were encouraged to speak freely without leading questions. Besides 15 Lawyers, 10 Judicial Officers and 20 Police Officers were interviewed in order to obtain their opinion regarding the implementation of UN Torture Convention in Criminal Justice System in Bangladesh.

\section{Interviews with Victims}

All are the victims of torture by Law enforcing Agencies (LEA). Table 1 shows 
the percentage of violation of human rights or torture by Law Enforcing Agency.

20 persons were interviewed of them 9 persons were physically tortured, 2 persons mentally tortured and 9 persons were tortured both physically and mentally.

Table 2 shows the percentage about the place of torture by Law Enforcing Agency. Here, 20 persons have been interviewed of whom 4 persons were tortured in Jail Custody, 13 persons were tortured in police custody and 3 persons are tortured both in jail and police custody.

In Table 3, out of 20 persons interviewed 15 persons were granted remand by the Magistrate, which is $75 \%$ and 4 persons were not taken into remand which is $20 \%$. One person does not fall in any category.

Table 4 shows how the persons detained/arrested tried to get relief from torture by giving bribe to the police authority or by using political influence during remand.

Table 4 shows that 15 persons were taken into remand under section 167 of the Cr. P. C. out of 20 persons interviewed. $66.66 \%$ of the remanded persons were forced to pay bribe to the police authority and $20 \%$ persons used political influence in order to get relief from physical and mental torture although there is constitutional bar against torture either during remand or otherwise.

Table 5 shows all persons had been subjected to blunt force, i.e. been beaten with fists or weapons and kicked with boots, $79 \%$ had suffered sharp violence, and $78 \%$ had been burnt. The weapons used in the beatings were the pointed police batons called lathi (which also can be used for stabbing), rifle butts, wooden canes, hot-water bottles, heavy wooden rollers and iron bars. Beating with land hockey clubs during interrogation were sometimes reported but many more described assaults with land hockey clubs during street demonstrations. When

Table 1. Kinds of torture.

\begin{tabular}{cccc}
\hline Physical Torture & Mental Torture & $\begin{array}{c}\text { Both mental and } \\
\text { physical torture }\end{array}$ & Total \\
\hline 9 & 2 & 9 & 20 \\
$(45 \%)$ & $(10 \%)$ & $(45 \%)$ & $(100 \%)$ \\
\hline
\end{tabular}

Table 2. Torture in custody.

\begin{tabular}{cccc}
\hline $\begin{array}{c}\text { Torture in Jail } \\
\text { Custody }\end{array}$ & $\begin{array}{c}\text { Torture in Police } \\
\text { Custody }\end{array}$ & $\begin{array}{c}\text { Both Jail and Police } \\
\text { Custody }\end{array}$ & Total \\
\hline 4 & 13 & 3 & 20 \\
$(20 \%)$ & $(65 \%)$ & $(15 \%)$ & $(100 \%)$ \\
\hline
\end{tabular}

Table 3. Arrested persons taken under remand and otherwise.

\begin{tabular}{ccccc}
\hline Remanded & Without remand & Sub-total & Not applicable & Total \\
\hline 15 & 4 & 19 & 1 & 20 \\
$(75 \%)$ & $(20 \%)$ & $(100 \%)$ & & \\
\hline
\end{tabular}


Table 4. How the victims try to get relief.

\begin{tabular}{cccc}
\hline Bribe given & Political influence used & Not applicable & Total \\
\hline 10 & 3 & 2 & 15 \\
$(66.66 \%)$ & $(20 \%)$ & & $(100 \%)$ \\
\hline
\end{tabular}

Table 5. Type of force in 20 torture victims.

\begin{tabular}{|c|c|c|}
\hline Type of force & Weapon & $\%$ \\
\hline \multicolumn{2}{|r|}{ Blunt force } & 100 \\
\hline & Police baton & 91.5 \\
\hline & Riffle but & 52.4 \\
\hline & Wooden cane & 42.7 \\
\hline & Hot water bottle & 21.2 \\
\hline & Roller & 20.7 \\
\hline & Iron bar & 19.5 \\
\hline & Knuckles & 16.8 \\
\hline & Land Hockey club & 8.5 \\
\hline \multicolumn{2}{|r|}{ Sharp violence } & 79.3 \\
\hline & Knife & 56.1 \\
\hline & Needle & 18.3 \\
\hline & Razor & 17.1 \\
\hline & Bayonet & 9.6 \\
\hline & Sword & 8.5 \\
\hline & Glass & 6.1 \\
\hline \multicolumn{2}{|r|}{ Burning } & 78.1 \\
\hline & Cigarette & 69.5 \\
\hline & Hot iron & 35.4 \\
\hline & Hot water & 19.5 \\
\hline & Gun shot & 6.1 \\
\hline
\end{tabular}

beaten with hot-water bottles it was most commonly under the feet. The sharp violence was in most cases executed by means of knives in a few cases with an axe, razor blades, bayonets, swords, and with shards of broken glass. Needles had been used exclusively for nail torture. Burning with cigarettes was alleged by $70 \%$ of the subjects, with hot iron by $35 \%$. Scalding with hot water was alleged by a few.

Statement given by one of the 20 accused arrested persons is stated herein below to reveal the nature of torture by police under their custody.

Aminul Haque a student of Law Department of Rajshahi University was arrested twice by Motihar Thana Police under Rajshahi District without warrant. He was first arrested on 23 March 2013 and for the second time in August 2014. He stated in the interview that both the times he was tortured physically by the police of Motihar Thana. He was also taken in remand for 4 days and was tortured 
inhumanly and mercilessly.

Of the 20 persons interviewed, $98 \%$ replied that there were no lawful grounds for their detention/arrest.

\section{Interviews with Lawyers}

Table 6 expressed the opinion against police remand of 100\% Lawyer.

Table 7 presents that out of 15 learned lawyers nobody said that UN Torture Convention is fully implemented in criminal Justice system in Bangladesh. 9 lawyers said that there is no implementation of CAT, which is $60 \%$. Rest of the 6 lawyers said that CAT is partly implemented in our criminal justice system.

\section{Interviews with Judicial Officers}

Table 8 presents that out of 10 judicial officers interviewed 4 said that High Court Division's directions regarding remand of an arrested person are followed, which is $40 \% .6$ officers said that it is not followed which is $60 \%$.

\section{Interviews with Police officers}

Table 9 shows 55\% police officers opined that in order to get information from the accused, remand is necessary, whereas $45 \%$ of them gave opinion against remand.

Torture is not only the problem of Bangladesh but also it's a global problem. It is found regularly in the media that physical or mental torture or inhuman treatments to human beings have become common features almost in every state. This is done either by law enforcing agencies or by private individuals. Guantanamo bay, Abu Garib jail etc are the example of that.

In light of the above discussion, it can be said that ill-treatment and torture have become so entrenched in Bangladesh that once someone is arrested it can be assumed that he or she will be subject to abuse. The culture of forcibly extorting confessions is deeply rooted within the law enforcement agencies in Bangladesh and is reportedly considered a normal practice. Bangladesh has yet to ratify the Optional Protocol to the Convention against Torture that provides for a visiting mechanism for the prevention of torture..$^{40}$ Bangladesh has not accepted the competence of either the Committee against Torture or the Human Rights Committee to receive individual complaints about torture. ${ }^{41}$

The political party in power uses torture as weapon to suppress the opposition party. Again when they are in opposition party they become victim of torture. In both cases law enforcing agencies are doing this job and they are bound to do so. Apart from the political persons torture is frequently practiced upon many other

${ }^{40}$ The text of the Optional Protocol is available at http://www.apt.ch/un/opcat/opcat.pdf. [Accessed on 2 June 2017].

${ }^{41}$ The Committee against Torture derives such a competence from a State party's declaration under Article 22 of the Convention against Torture and the Human Rights Committee from the State becoming party to the Optional Protocol to the International Covenant on Civil and Political Rights. 
Table 6. Legal foundation of torture under remand and opinion of lawyers about granting remand.

\begin{tabular}{ccc}
\hline Legal & No Legal Foundation & Total \\
\hline & 15 & 15 \\
$\mathrm{x}$ & $(100 \%)$ & $(100 \%)$ \\
\hline
\end{tabular}

Table 7. Implementation of UN torture convention.

\begin{tabular}{cccc}
\hline Fully implemented & No implementation & Partly implemented & Total \\
\hline & 9 & 6 & 15 \\
$\mathrm{x}$ & $(60 \%)$ & $(40 \%)$ & $(100 \%)$ \\
\hline
\end{tabular}

Table 8. Whether the guidelines of the honorable high court division in respect of remand of an arrested person is followed.

\begin{tabular}{ccc}
\hline $\begin{array}{c}\text { HC directions are followed in respect of remand } \\
\text { of an arrested person. }\end{array}$ & Not followed & Total \\
\hline $\begin{array}{c}4 \\
(40 \%)\end{array}$ & 6 & 10 \\
$(60 \%)$ & $(100 \%)$ \\
\hline
\end{tabular}

Table 9. Arguments against/in favor of remand.

\begin{tabular}{ccc}
\hline Argument in favor of granting remand & Against granting remand & Total \\
\hline 11 & 9 & 20 \\
$(55 \%)$ & $(45 \%)$ & $(100 \%)$ \\
\hline
\end{tabular}

persons even on many innocent persons.

The country's police force is not the only state agency practicing torture. Paramilitary forces like the Rapid Action Battalion, the armed forces, the border security forces, intelligence agencies such as the Directorate General of Forces Intelligence (DGFI) and special cells such as the Task Force for Interrogation and the Joint Interrogation Cell also practice torture. The latter two agencies, by the very nature of their mandate, are professionally trained to extract confessions from detainees, for which torture is the most common tool. Deaths by the $\mathrm{RAB}$ through crossfire are reported frequently. Custodial deaths are also reported repeatedly. Bangladesh Constitution expressly prohibits torture. Other laws like CrPC, Penal Code speaks against torture. On the other hand Bangladesh Constitution and Penal Code provides immunity to the perpetrators of torture if they are Government officials.

As widely acknowledged, impunity for torture is one of the main factors that facilitates further violations in Bangladesh. It also perpetuates injustice caused to the victims of torture, irrespective of whether they have been targeted as individuals or members of communities and/or political parties. For most, the right to reparation appears to exist in theory only.

As a signatory of the UDHR, the ICCPR and the UN Torture Convention Bangladesh has obligation to criminalize torture. But Bangladesh fails to enact 
such laws yet. Moreover sections 54 and 167 of $\mathrm{CrPC}$ and section 3 of Special Powers Act, 1974 are misused by police relating to arrest and remand respectively. High Court Division in BLAST and others vs Bangladesh and Saifuzzaman vs State case provided some guidelines and directions regarding investigation, arbitrary arrest and remand. Those guidelines and directions are not followed in all cases. This is why the number of incidents of torture is not decreasing apparently. From the study it is seen that though there is an attempt but so far UN Torture Convention is not implemented in criminal justice system in Bangladesh. To award relief to the people from the curse of torture the following recommendations are necessary for Bangladesh Government and all concerned to overcome the situation:

\section{Recommendations}

1) The Torture and Custodial Death (Prevention) Act, 2013 should be amended as soon as possible.

2) Amending the definition of torture in Section 2 (6) of the Torture and Custodial Death (Prevention) Act, 2013 to bring it into closer conformity with article 1 of CAT.

3) In Section 4, the phrase "The Court having jurisdiction" should be clarified.

4) Section 5 of the Act should be amended by adding the provision of judicial investigation instead of the current provision of investigation against the law enforcement agencies by the law enforcement agencies.

5) The Act does not include a definition of "person" to remove ambiguity of meaning of some provisions like sections 6 (1), 7 (1), 8 (3) and 13 (1), (2) of the Act. Therefore, the Act should include a definition of the word "person" mentioned especially in section 13 (1) meaning public official or other person acting in an official capacity in conformity with CAT.

6) Amending section 15 of the Torture and Custodial Death (Prevention) Act, 2013: providing for adequate payment of compensation to the victims of torture.

7) The amount of compensation should be given directly to the victims or aggrieved person of torture and custodial death.

8) The aggrieved person meaning family member and legal successor should be included in this Act.

9) Amending the Torture and Custodial Death (Prevention) Act, 2013: providing for protection to witnesses related to torture prosecutions.

10) The punishment of the offences mentioned in the Act should be increased.

11) The Rules under section 20 should be formed as soon as possible.

12) The word "Jantrana" (Distress) instead of "Nirjatan" (Persecution) should be used in this Act following Article 35 (5) of the Constitution.

13) The gender issue is missing in this Act. For example, female accused should be arrested and dealt with by female police not by male police.

14) Awareness and knowledge of this Act should be disseminated to the mass people. 
15) Law enforcement agencies must show their identity (ID) card during arrest.

16) Law enforcement agencies should be in official uniform and not in civil dress at the time of arresting a person.

17) Arrest must be made in the presence of two neighbours as witnesses.

18) Law enforcement agencies must inform the family member or friend of arrested person as soon as possible about the arrest and place where arrested persons are taken.

19) A General Dairy (GD) should be made immediately whenever any arrested person is brought to Police station or Thana.

20) Ensuring the protection of the persons who file a case against a member of law enforcement agencies.

21) If any custodial death is occurred, this incident must be informed to the National Human Rights Commission (NHRC), Bangladesh within 24 hours.

22) Amending the National Human Rights Commission Act, 2009 to empower the NHRC to investigate human rights violations by law enforcement agencies.

23) The Parliament with the initiative of Ministry of Law, Justice \& Parliamentary Affairs should amend sections 54,167, 344 of the Code of Criminal Procedure according to the guidelines provided by the Supreme Court in the BLAST case.

24) The guidelines and directions given by the High Court Division in BLAST and Others vs Bangladesh and Saifuzzaman vs State cases regarding arrest, investigation and remand should be strictly followed.

25) The Penal Code should define and criminalize torture as required by the CAT.

26) The judiciary should exercise a close scrutiny on conditions of detention and interrogation by the police during the remand procedure.

27) Magistrates should declare inadmissible any statement which is made as a result of torture, in conformity with Articles 12 and 13 of the UN Convention against Torture, and the prohibition of self-incriminating statements enshrined in Article 35 (4) of the Constitution of Bangladesh.

28) Bangladesh should consider amending Article 46 of the Constitution in order to limit the power given to Parliament by excluding acts of torture and other cruel, inhuman or degrading treatment or punishment from the scope of acts for which public officials can be indemnified.

29) The immunity provisions for public officials that engage in torture within the Code of Criminal Procedure must be repealed in particular Section 132 of the Code, and other legal provisions which impede alleged victims of human rights violations from lodging complaints against State officials suspected of being the authors, instigators or accomplices of such acts.

30) Investigation department should be separated from the police department where police is accused. 
31) Police personnel should be trained on human rights and Police should not be used for political motives.

32) Judiciary and administration need to be free from corruption.

33) Honest persons and persons of high moral standard should be appointed as police officers and judicial officers.

34) Human rights should be included in the curriculum of School, College and University in order to make the students aware of its violation

35) Exemplary punishment should be inflicted on the perpetrators of torture.

36) National Human Rights Council should maintain its independence and impartiality.

37) More power and autonomy should be given to NHRC. Necessary skilled manpower as required by the NHRC should be appointed for performing its act smoothly. Strengthening its investigative functions is needed.

38) Bangladesh should submit its report to the Committee against Torture regularly.

39) The victim of torture should raise their voice against the perpetrators. The Human Rights NGO can play a vital role in this respect.

40) Awareness campaigns by the government, media and NGO should be pursued.

\section{Conclusion}

Bangladesh is a democratic country which achieved her independence in 1971 from Pakistan. It is a developing country which is geographically very important for South Asian peace and security. Bangladesh always maintains a good diplomatic relation with different countries according to international norms and values. It is very unfortunate that torture in lawful custody is a common scenario in Bangladesh and it is a much talked topic in criminal justice system at this moment in Bangladesh. Torture is a criminal offence and it is against the humanity which is hated by all the civilized society and community but this practice is prevailing everywhere in Bangladesh. Most of the human rights organizations have thrown their attention in to this matter. They are trying to work against such malpractices. Lawyers, jurists, teachers, and other professionals are speaking against this inhuman practice but no effective means and measures to stop this torture can be seen till now. The Government of Bangladesh has ratified the Convention against Torture and Other Cruel, Inhuman or Degrading Treatment or Punishment and enacted the Torture and Custodial Death (Prevention) Act, 2013 but it has hardly taken any step for effective removal of torture. As a result, this inhuman culture in criminal justice system is increasing day by day. Sometimes, torture is used as a vital weapon to stop the voice of political opposition. So, with the awareness of NGO and various professionals the Government should start to take effective steps to eradicate this inhuman practice right now with the effective implementation of United Nation Convention against Torture. 


\section{References}

2016 Country Reports on Human Rights Practices. Report. https://www.state.gov/j/drl/rls/hrrpt/2016/sca/265532.htm

African Charter on Human and Peoples' Rights. (1986).

American Convention on Human Rights. (1969).

American Declaration of the Rights and Duties of Man (ADRDM). (1948).

Amnesty International (2008). Report 08: At a Glance. http://web.archive.org/web/20080708202906 http://thereport.amnesty.org/eng/report-08-at-a-glance

Amnesty International Report 2005 and 2006.

Constitution of the Peoples Republic of Bangladesh. (1972).

Convention against Torture and other Cruel, Inhuman or Degrading Treatment or Punishment. (1984).

European Convention on Human Rights and Fundamental Freedom (ECHRFF). (1950).

Fact Finding Report of Odhikar.

General Information Leaflet: Torture and Ill Treatment in the War on Terror. http://www.amnesty.org/en/library/info/ACT40/014/2005/en

Halim, M. A. (2009). The Legal System of Bangladesh. Dhaka: CCB Foundation.

Hossain, H. (2005). Human Rights in Bangladesh 2004. Dhaka: Ain O Salish Kendra.

Human Rights Watch (2010). World Report 2010 Bangladesh. http://www.unhcr.org/refworld/docid/4b586cfb37.html

International Covenant on Civil and Political Rights. (1966).

Kulshreshtha's, V. D. (1995). Landmarks in Indian Legal and Constitutional History (7th ed.). Lucknow: Eastern Book Company.

Mahumudur Alleges Torture in Remand. http://www.bdnews24.com/details.php?id=164100\&cid=2

Malik, S. (2007). Arrest and Remand: Judicial Interpretation and Police Practice. Bangladesh Journal of Law, Special Issue, 277.

Odhikar (2014). Six-Months Human Rights Monitoring Report (p. 5). Dhaka: Human Rights Organization. http://www.omct.org/files/2014/07/22773/hr_report_jan_june_2014_en.pdf

Odhikar (2017). Human Rights Monitoring Report. Dhaka: Human Rights Organization. https://www.forum-asia.org/uploads/wp/2017/04/human-rights-monitoring-report-Ma rch-2017-Eng.pdf

Odhikar's Human Rights Monitoring Report (p. 2). (2010). Cops Slammed for Custodial Deaths. The Daily Star, 6 July 2010.

http://www.thedailystar.net/newDesign/news-details.php?nid=145551

Speedy Trial Act. (2002).

The Bangladesh Today. (2004). Dhaka: English Daily Newspaper.

The Criminal Procedure Code. (1898).

The Daily Prothom Alo and Odhikar (2015). Bangladesh: Human Rights Report (p. 26). Dhaka: Human Rights Organization.

https://www.fidh.org/IMG/pdf/20161114_bangladesh_odhikar_hrreport_2015.pdf

The Daily Star. (2000). Dhaka: English Daily Newspaper. 
The Public Safety Act. (2000).

The Special Powers Act. (1974).

UN United Nations Treaty Collection.

http://treaties.un.org/pages/ViewDetails.aspx?src=TREATY\&mtdsg_no=IV-9\&chapter $=4$ \&lang $=$ en

Universal Declaration of Human Rights. (1948). 